\title{
G7H, a New Soybean mosaic virus Strain: Its Virulence and Nucleotide Sequence of CI Gene
}

Yul-Ho Kim, National Crop Experiment Station, RDA, Suwon 441-100, Korea; Ok-Sun Kim, National Seed Management Office, MAF, Miryang 627-911, Korea; Bong-Choon Lee, National Yeongnam Agricultural Experiment Station, RDA, Miryang 627-130, Korea; Jung-Kyung Moon, National Crop Experiment Station, RDA, Suwon 441-100, Korea; Sang-Chul Lee, Department of Agronomy, Kyungpook National University, Taegu 702-701, Korea; and Jang-Yong Lee, National Crop Experiment Station, RDA, Suwon 441-100, Korea

\begin{abstract}
Kim, Y.-H., Kim, O.-S., Lee, B.-C., Moon, J.-K., Lee, S.-C., and Lee, J.-Y. 2003. G7H, a new Soybean mosaic virus strain: Its virulence and nucleotide sequence of CI gene. Plant Dis. 87:1372-1375.

A new Soybean mosaic virus (SMV) strain was isolated in Korea and designated as G7H. Its virulence on eight differentials and 42 Korean soybean cultivars was compared with existing SMV strains. G7H caused the same symptoms as G7 did on the eight differential cultivars. However, it caused different symptoms on the G7-immune Korean soybean cultivars; G7H caused necrosis in Suwon 97 (Hwangkeumkong) and Suwon 181 (Daewonkong), and a mosaic symptom in Miryang 41 (Duyoukong), while G7 caused only local lesions on those varieties. The nucleotide sequence of the cylindrical inclusion region of $\mathrm{G} 7 \mathrm{H}$ was determined and compared with other SMV strains. G7H shared 96.3 and $91.3 \%$ nucleotide similarities with G2 and G7, respectively; whereas G7 shared $95.6 \%$ nucleotide similarity with G5H.
\end{abstract}

Soybean mosaic virus (SMV) is the most prevalent soybean (Glycine max (L.) Merr.) disease in Korea (18). Since it was reported in 1977 (4), SMV has been a serious problem for soybean production, especially in the central parts of Korea. It causes serious damage and effects on plant growth, seed chemical components, yield, and germination rates $(16,17)$. Plants developing necrotic symptoms produce virtually no seed (4).

New SMV strains were identified during the last two decades. G3A and G5H were identified in 1983 (3). G5H was first reported as a mutant derived from the G5 strain, causing the same reactions in the soybean differentials except for Suwon 97. However, it was not clear if G5H was a mutant of G5 or not (2). Five strains, G1, G2, G5, G6, and G7, that caused mosaic or necrotic symptoms were reported in 1986 (5). G5HD was reported in 1991 and caused mosaic symptoms on Marshall and Paldalkong cultivars (12).

In 1999, a new SMV isolate that caused mosaic and necrotic symptoms on the Korean cultivars resistant to $\mathrm{G} 5 \mathrm{H}$ and $\mathrm{G} 7$ was reported (Y.-H. Kim, unpublished). More than $50 \%$ of the SMV damage in Suwon soybean fields was due to this new strain

Corresponding author: Y.-H. Kim

E-mail: kimyuh@hanmail.net

Accepted for publication 3 July 2003.

Publication no. D-2003-0915-03R

(C) 2003 The American Phytopathological Society compared with the $80 \%$ caused by G5 in 1981 and $65 \%$ for G5H in 1989. This new isolate, $\mathrm{G} 7 \mathrm{H}$, is now the most prevalent strain and different from $\mathrm{G} 5 \mathrm{H}$ or $\mathrm{G} 7$ in symptom expression of soybean cultivars.

Cylindrical inclusions (CI) are produced by the infection of potyviruses (7). The antisera (polyclonal antibodies) produced against viral $\mathrm{CI}$ proteins can be used to detect the presence of a potyvirus. However, to distinguish among the different potyviruses, monoclonal antibodies made against virus-specific epitopes which cluster in the C-terminal region should be used (8). The complete nucleotide sequences of SMV strains G2 and G7 have been determined by Jayaram et al., and the magnitude of the variation was in the order of $\mathrm{P} 3, \mathrm{P} 1$, and the CI region in SMV (10).

The objective of this study was to report the virulence and the nucleotide sequence of the CI region of the new G7H SMV strain.

\section{MATERIALS AND METHODS}

SMV strains. Nine strains, G1, G2, G3, G4, G5, G6, G7, G5H, and G7H, were used in this study. SMV G1-VA (PV-571), G3 (PV-616), G4-VA (PV-572), G6 (PV612), and G7 (PV-613) were provided by the American Type Culture Collection (Manassas, VA). G5H strain was obtained from E. K. Cho (Andong National University, Korea). G2, G5, and G7H strains were seedborne isolates or isolated from soybean fields. Each strain was confirmed by inoculating the soybean differential varieties of Cho \& Goodman (6) and Korean soybean cultivars such as Hwangkeum- kong, Daewonkong, Duyoukong, and Myeongjunamulkong.

Virulence test. Each SMV strain used in this study was maintained in soybean cv. Kwangankong (Suwon 159). Inoculum was prepared by homogenizing leaves showing mosaic symptoms in $0.01 \mathrm{M}$ sodium phosphate buffer $(\mathrm{pH} 7.0,5 \mathrm{ml}$ per gram of leaf tissue) with a chilled mortar and pestle. Inoculations were made by rubbing inoculum-soaked cotton swabs on fully expanded primary leaves predusted with Carborundum powder, and the leaves were rinsed immediately with tap water. All inoculations of SMV strains were performed in the greenhouse at average daily minimum and maximum temperatures of $20^{\circ} \mathrm{C}$ and $32^{\circ} \mathrm{C}$, respectively. Forty-two Korean soybean cultivars were planted in 16-cm-diameter pots. Five pots (three plants per pot) were prepared for each cultivar and inoculated with G2, G5, G7, G5H, and G7H SMV strains, respectively. The symptoms were recorded 2 months following inoculation. These tests were repeated three times. To confirm the infection of SMV, the third trifoliolate leaves from all symptomless plants were removed at growth stage V4 and homogenized to extract total viral RNA. Reverse transcription-polymerase chain reaction (RT-PCR) assay was employed for SMV detection (14). A set of primers was designed for amplifying the 1,385-bp fragment at positions from 4176 to 5560 , including the CI coding region identified in the $\mathrm{G} 2$ strain (10). The forward primer, CIP 5' (5'GCATTCAACTGTGCGCTTAAAGAAT$3^{\prime}$ ), was homologous to 4176 to $4200 \mathrm{nt}$ of SMV-G2 (S42280), and the reverse primer, CIP 3' (5'-TTGAGCTGCAAAAATTTACTCACTT- $3^{\prime}$ ), was complementary to 5535 to 5560 nt. Symptomless plants from which SMV was not detected by RT-PCR were assumed to be resistant to SMV.

RT-PCR assay and sequencing. Viral RNA was isolated using the RNA isolation system (Promega, Madison, WI) according to manufacture's instructions. For RT-PCR amplification of the CI region, primers were designed based on the sequences reported by Jayaram et al. (10). Four sets of primers were used to amplify the whole $1.9 \mathrm{~kb}$ of the CI region (Table 1). cDNA synthesis and PCR amplification were performed in one tube. RT-PCR reactions 
were performed in a tube with $50 \mu \mathrm{l}$ of reaction mixture containing $10 \mu \mathrm{l} \mathrm{AMV} / \mathrm{Tfi}$ $5 \times$ reaction buffer, $1 \mu \mathrm{l}$ dNP mix $(10 \mathrm{mM}$ each), $2 \mu \mathrm{lgSO}_{4}(25 \mathrm{mM}), 1 \mu \mathrm{l}$ each primer $(50 \mathrm{pmol}), 1 \mu \mathrm{l}$ AMV reverse transcriptase ( 5 units $/ \mu$ l), $1 \mu \mathrm{l}$ Tfi DNA polymerase ( 5 units $/ \mu \mathrm{l}), 5 \mu$ template RNA, and sterile water made up to the final volume of $50 \mu \mathrm{l}$. Thermocycling was programmed as follows: cDNA synthesis at $48^{\circ} \mathrm{C}$ for $45 \mathrm{~min}$ and RNA/cDNA/primer denaturation at $94^{\circ} \mathrm{C}$ for $2 \mathrm{~min}$, followed by 40 cycles for template denaturation at $94^{\circ} \mathrm{C}$ for $30 \mathrm{~s}$, primer annealing at $60^{\circ} \mathrm{C}$ for $1 \mathrm{~min}$, extension at $68^{\circ} \mathrm{C}$ for $2 \mathrm{~min}$, and a final extension at $68^{\circ} \mathrm{C}$ for $7 \mathrm{~min}$. The amplified products were separated by $0.8 \%$ agarose gel electrophoresis. The bands of interest were excised from the gel and purified using SUPREC-01 (TaKaRa, Seta 3-4-1, Otsu, Shiga 520-2193, Japan). The DNA fragments were directly sequenced using BigDye terminator cycle sequencing ready reaction kit with AmpliTaq DNA polymerase, FS (PE Applied Biosystems, Boston, MA).

Table 1. Four primer sets for amplification of cylindrical inclusion region of Soybean mosaic virus (SMV)

\begin{tabular}{|c|c|c|}
\hline Primer position $^{\mathrm{a}}$ & Primer sequence & Expected size $(b p)^{b}$ \\
\hline $3574-3598\left(5^{\prime}\right)$ & GCAAGTTAAAGGCATTTTTCAGCAC & \multirow[t]{2}{*}{687} \\
\hline $4236-4260\left(3^{\prime}\right)$ & ATTCGCACTCTCTCCCTGGAGTCGT & \\
\hline $4176-4200\left(5^{\prime}\right)$ & GCATTCAACTGTGCGCTTAAAGAAT & \multirow[t]{2}{*}{401} \\
\hline $4552-4576\left(3^{\prime}\right)$ & CAATCAATATCAAGAGTCACTCCAT & \\
\hline $4526-4550\left(5^{\prime}\right)$ & CATAGTCGCAACAAACATCATTGAG & \multirow[t]{2}{*}{555} \\
\hline $5056-5080\left(3^{\prime}\right)$ & GGACAATTGAGGTGGATACCTTGAC & \\
\hline $5011-5035\left(5^{\prime}\right)$ & CATATCAGTTTGTTGGGCAGTGGGT & \multirow[t]{2}{*}{550} \\
\hline $5536-5560\left(3^{\prime}\right)$ & TTGAGCTGCAAAAATTTACTCACTT & \\
\hline
\end{tabular}

a Primer positions are issued from GenBank accession no. S42280 (SMV-G2).

${ }^{\mathrm{b}} \mathrm{bp}=$ base pair.

\section{RESULTS}

For screening SMV isolates, 42 samples of soybean leaves showing mosaic and/or necrotic symptoms were collected from the soybean fields of Suwon in 1997, and 11 virus isolates obtained from these samples were used for inoculating the differentials and some Korean soybean cultivars (Table 2). Among the 11 isolates tested, one isolate caused different responses from other strains previously identified. This isolate caused the same symptoms as G7 on the differentials. However, different results occurred when Korean varieties such as Suwon 97, Suwon 181, and Miryang 41 were used. This isolate caused local lesions and systemic necrosis on Suwon 97 and Suwon 181, whereas G7 caused local lesions only in the inoculated leaves. It caused a mosaic symptom on Miryang 41, whereas G5H caused local lesions only (Table 2). From these results, it was concluded that this isolate was different from G7 or G5H and was designated as G7H. G7H caused more severe symptoms than G5H in many susceptible soybean cultivars at the same inoculation conditions. G7H caused $100 \%$ systemic necrosis when in-

Table 2. Phenotype ${ }^{\mathrm{a}}$ of soybean differentials following inoculation with different Soybean mosaic virus (SMV) strains

\begin{tabular}{|c|c|c|c|c|c|c|c|c|c|}
\hline \multirow{2}{*}{$\begin{array}{l}\text { Differential } \\
\text { cultivars }\end{array}$} & \multicolumn{9}{|c|}{ SMV strains } \\
\hline & G1 & G2 & G3 & G4 & G5 & G5H & G6 & G7 & G7H \\
\hline Rampage & $-/ \mathrm{M}^{\mathrm{b}}$ & $-/ \mathrm{M}$ & $-/ \mathrm{M}$ & $-/ \mathrm{M}$ & $-/ \mathrm{M}$ & $-/ \mathrm{M}$ & $-/ \mathrm{M}$ & $-/ \mathrm{M}$ & $-/ \mathrm{M}$ \\
\hline Clark & $-/ \mathrm{M}$ & $-/ \mathrm{M}$ & $-/ \mathrm{M}$ & $-/ \mathrm{M}$ & $-/ \mathrm{M}$ & $-/ \mathrm{M}$ & $-/ \mathrm{M}$ & $-/ \mathrm{M}$ & $-/ \mathrm{M}$ \\
\hline Davis & $-1-$ & $-1-$ & $-1-$ & $\mathrm{L} / \mathrm{N}$ & $-/ \mathrm{M}$ & $-/ \mathrm{M}$ & $-/ \mathrm{M}$ & $-/ \mathrm{M}$ & $-/ \mathrm{M}$ \\
\hline York & $-1-$ & $-1-$ & $-1-$ & $\mathrm{L} / \mathrm{N}$ & $-/ \mathrm{M}$ & $-/ \mathrm{M}$ & $-/ \mathrm{M}$ & $-/ \mathrm{M}$ & $-/ \mathrm{M}$ \\
\hline Marshall & $-1-$ & $\mathrm{L} / \mathrm{N}$ & $\mathrm{L} / \mathrm{N}$ & $\mathrm{L} / \mathrm{N}$ & $-1-$ & $-1-$ & $\mathrm{L} / \mathrm{N}$ & $\mathrm{L} / \mathrm{N}$ & $\mathrm{L} / \mathrm{N}$ \\
\hline Ogden & $-1-$ & $-1-$ & $\mathrm{L} / \mathrm{N}$ & $\mathrm{L} / \mathrm{N}$ & $-1-$ & $-1-$ & $-1-$ & $\mathrm{L} / \mathrm{N}$ & $\mathrm{L} / \mathrm{N}$ \\
\hline Kwanggyo & $-1-$ & $-1-$ & $-1-$ & $-1-$ & $\mathrm{L} / \mathrm{N}$ & $\mathrm{L} / \mathrm{N}$ & $\mathrm{L} / \mathrm{N}$ & $\mathrm{L} / \mathrm{N}$ & $\mathrm{L} / \mathrm{N}$ \\
\hline Buffalo & $-1-$ & $-1-$ & $-1-$ & $-1-$ & $-1-$ & $-1-$ & $-1-$ & $\mathrm{L} / \mathrm{N}$ & $\mathrm{L} / \mathrm{N}$ \\
\hline Suwon 97 & $-1-$ & $-1-$ & $-1-$ & $-1-$ & $\mathrm{L} /-$ & $\mathrm{L} / \mathrm{N},-$ & $\mathrm{L} /-$ & $\mathrm{L} /-$ & $\mathrm{L} / \mathrm{N}$ \\
\hline Suwon 181 & $-1-$ & $-1-$ & $-1-$ & $-1-$ & $\mathrm{L} /-$ & $\mathrm{L} / \mathrm{N}$ & $\mathrm{L} /-$ & L/- & $\mathrm{L} / \mathrm{N}$ \\
\hline Miryang 41 & $-/ \mathrm{M}$ & $-/ \mathrm{M}$ & $-/ \mathrm{M}$ & $-/ \mathrm{M}$ & L/- & L/- & L/- & L/- & $-/ \mathrm{M}$ \\
\hline Suwon 172 & $-1-$ & $-1-$ & $-1-$ & $-1-$ & $-1-$ & $-1-$ & $-1-$ & $-1-$ & $-1-$ \\
\hline
\end{tabular}

a Symptoms: $-=$ symptomless, $\mathrm{M}=$ mosaic, $\mathrm{N}=$ necrosis, $\mathrm{L}=$ local lesions.

${ }^{\mathrm{b}}$ Format for symbols: reaction on inoculated primary leaves/reaction on upper leaves.

Table 3. Phenotypic ${ }^{\mathrm{a}}$ reactions of 42 Korean soybean cultivars to Soybean mosaic virus (SMV) strains G7H, G5H, G7, G5, and G2

\begin{tabular}{|c|c|c|c|c|c|}
\hline \multicolumn{5}{|c|}{ SMV strains } & \multirow[b]{2}{*}{ Soybean cultivars ${ }^{b}$} \\
\hline G7H & G5H & G7 & G5 & G2 & \\
\hline _- & - & - & - & - & M69 (Ilpumgeomjeongkong), S179 (Geomjeongkong2), S172 (Myeongjunamulkong) \\
\hline- & - & $\mathrm{N}$ & - & - & S160 (Pureunkong) \\
\hline ST & - & - & - & - & K1 (Soyangkong) \\
\hline $\mathrm{N}$ & - & - & - & - & $\begin{array}{l}\text { I5 (Pungsannamulkong), M67 (Jangmikong), S133 (Muhankong), S141 (Jangsukong), S169 } \\
\text { (Jinpumkong), S177 (Jinpumkong2), S185 (Sodamkong) }\end{array}$ \\
\hline $\mathrm{N}$ & $\mathrm{N}$ & - & - & - & $\begin{array}{l}\text { I6 (Alchankong), M58 (Dajangkong), S86 (Jangyeobkong), S97 (Hwangkeumkong), S132 } \\
\text { (Pokwangkong), S142 (Mallikong), S181 (Daewonkong) }\end{array}$ \\
\hline $\mathrm{N}$ & - & $\mathrm{N}$ & - & - & S151 (Sinpaldalkong2) \\
\hline $\mathrm{N}$ & $\mathrm{N}$ & $\mathrm{N}$ & - & - & S155 (Geomjeongkong1) \\
\hline $\mathrm{N}$ & $\mathrm{N}$ & - & $\mathrm{N}$ & - & S121 (Baegunkong), S145 (Taekwangkong), M8 (Saealkong) \\
\hline M & - & - & - & M & M41 (Duyoukong), M45 (Geumgangkong) \\
\hline M & - & M & M & M & M43 (Hannamkong) \\
\hline M & M & - & M & M & M33 (Bukwangkong) \\
\hline M & M & M & M & - & S186 (Seonheukkong), M31 (Keunolkong), S167 (Hwaeomputkong) \\
\hline M & M & M & M & M & $\begin{array}{l}\text { M19 (Eunhakong), M21 (Namhaekong), M25 (Danweonkong), M28 (Samnamkong), M50 (So- } \\
\text { baegnamulkong), S85 (Danyeobkong), S158 (Danbaegkong), S159 (Kwangankong), S168 } \\
\text { (Seokryangputkong), S182 (Tawonkong), S184 (Somyeongkong) }\end{array}$ \\
\hline
\end{tabular}

\footnotetext{
a Symptoms: $-=$ symptomless, $\mathrm{M}=$ mosaic, $\mathrm{N}=$ necrosis, $\mathrm{ST}=$ stunting.

${ }^{\mathrm{b}}$ Soybean cultivars: $\mathrm{S}=$ Suwon, $\mathrm{M}=$ Miryang, $\mathrm{I}=\mathrm{Iksan}, \mathrm{K}=$ Kangwon.
} 
oculated on Suwon 97, whereas about $70 \%$ of Suwon 97 inoculated with G5H did not show this symptom.

Based on the response to SMV strains G7H, G5H, G7, G5, and G2, 42 soybean cultivars could be divided into 13 groups (Table 3). Again, the results clearly showed that $\mathrm{G} 7 \mathrm{H}$ caused different responses from those of $\mathrm{G} 7$ and $\mathrm{G} 5 \mathrm{H}$, and $\mathrm{G} 7 \mathrm{H}$ caused disease symptoms on most cultivars used (Table 3). Only M69, S179, S172, and S160 of the 42 cultivars were resistant (symptomless) to G7H. This was comparable to 16 cultivars resistant to $\mathrm{G} 5 \mathrm{H}$, and 24 cultivars to G7 strain, respectively. Three soybean cultivars, Miryang 69, Suwon 172, and Suwon 179, were resistant to the five SMV stains, and virus was not detected from symptomless trifoliolate leaves by RT-PCR assay. Suwon 160 was susceptible to G7, causing necrosis, but was resistant to $\mathrm{G} 7 \mathrm{H}, \mathrm{G} 5 \mathrm{H}, \mathrm{G} 5$, and $\mathrm{G} 2$ strains. Strain G7H could induce symptoms on eight cultivars (stunting in Soyangkong and necrosis in seven cultivars in the fourth group) resistant to the other strains. Miryang 43 and Suwon 151 were resistant to $\mathrm{G} 5 \mathrm{H}$, and mosaic and necrosis symptoms were caused by G7H and G7, respectively. Eleven cultivars were susceptible to all strains used and showed mosaic symptoms. Necrotic symptoms were observed in the Suwon 155 cultivar infected with SMV strains G7H, G5H, and G7.

The CI nucleotide sequences of G5, $\mathrm{G} 5 \mathrm{H}$, and $\mathrm{G} 7 \mathrm{H}$ were determined and compared with those of G2 and G7. There were few nucleotide differences in the sequence of the CI of the five strains. The comparison of G7H with G5H showed 169 nucleotide substitutions, whereas G5H showed higher similarity with that of G5, having only 29 nucleotide differences.

The nucleotide and deduced amino acid sequences of the five strains were compared (Table 4). G7H showed $96.3 \%$ nucleotide identity with $\mathrm{G} 2$, and 91.3 and $90.7 \%$ with $\mathrm{G} 7$ and $\mathrm{G} 5 \mathrm{H}$, respectively. The deduced amino acid sequence homology showed a similar pattern to that shown in nucleotide sequence homology. Strains G7 and G2 showed more amino acid sequence homology than G7H did with G7 or G5H. The two strains G5H and G5 shared $99.1 \%$ identity in this region.

\section{DISCUSSION}

A new SMV strain, G7H, was isolated and confirmed by pathogenicity studies and nucleotide sequence homology of CI. G7H became a major SMV strain, accounting for $36 \%$ of the total SMV infection in a nationwide survey in 1999 (13). It also caused more severe symptoms than any other strains identified so far.

Since it was not possible to distinguish the virulence difference between G7 and G7H with standard differential cultivars only, it was necessary to employ some Korean cultivars to test the virulence (Table 2). From the results of screening SMV strains with 42 Korean cultivars (Table 3), several soybean cultivars such as Suwon 160, Miryang 43, Suwon 181, and Miryang 41 should be added to the differentials. The screening system employed here will be helpful in finding the new strains.

G5 and $\mathrm{G} 5 \mathrm{H}$ were the major strains causing significant damage until $\mathrm{G} 7 \mathrm{H}$ was found in 1999 (15). There is always a chance for development of a new strain such as G7H, because the Korean peninsula and Manchuria are the places of origin of soybean, and resistant varieties of SMV may continuously arise.

Resistant genes in soybean have been studied, and three genes, $R s v 1, R s v 3$, and $R s v 4$, have been reported $(1,9,11)$. The resistance genes of differential cultivars and the Korean cultivars are now being studied. The results presented here will be helpful in screening the SMV strains and in breeding SMV-resistant varieties.

Five SMV strains compared in this study shared 95 to $99 \%$ amino acid sequence homologies in the CI region (Table 4). The deduced amino acid sequence of strains G7 and G2 from nucleotides 4938 to 4949 were PEIH and VIDT, respectively. There were 12 mismatched bases. Three other strains, G5H, G7H, and G5, also had the same amino acid sequence, PEIH. Although G2 is a relatively mild strain, it has not been determined if the sequence of PEIH is involved in the virulence of SMV. Sano et al. (19) reported that no apparent correlation existed between the nucleotide sequence of coat protein gene of the SMV isolates and their pathogenicities in soybean cultivars. It has not been reported if the amino acid compositions in the CI regions are responsible for the pathogenic-

Table 4. Percent nucleotide and deduced amino acid sequence similarities of the cylindrical inclusion region of Soybean mosaic virus strains

\begin{tabular}{ccccccc}
\hline & & \multicolumn{5}{c}{ Nucleotide $^{\mathbf{a}}$} \\
\cline { 3 - 7 } \multicolumn{2}{c}{ Strains } & G5H & G5 & G7 & G7H & G2 \\
\hline \multirow{3}{*}{ Amino } & G5H & 100 & 98.2 & 95.6 & 90.7 & 90.2 \\
acid & G5 & 99.1 & 100 & 95.5 & 91.0 & 90.6 \\
& G7 & 98.3 & 97.8 & 100 & 91.3 & 91.2 \\
& G7H & 96.4 & 95.9 & 96.1 & 100 & 96.3 \\
& G2 & 95.9 & 95.4 & 95.6 & 97.6 & 100 \\
\hline
\end{tabular}

a GenBank accession numbers (G5H, AY169284; G5, AY169285; G7, AF241739; G7H, AY169283; and G2, S42280). ity of SMV in soybeans. Nevertheless, it is interesting that there is higher homology between $\mathrm{G} 7 \mathrm{H}$ and $\mathrm{G} 2$ than between $\mathrm{G} 7 \mathrm{H}$ and $\mathrm{G} 5 \mathrm{H}$ or $\mathrm{G} 7$, because $\mathrm{G} 7$ and $\mathrm{G} 5 \mathrm{H}$ are more closely related to $\mathrm{G} 7 \mathrm{H}$ than $\mathrm{G} 2$ based on virulence on soybean differentials. This variation of $\mathrm{CI}$, however, may be valuable for detection and differentiation of SMV strains in RT-PCR and restriction fragment length polymorphism assay.

\section{ACKNOWLEDGMENTS}

We thank E. K. Cho for kindly offering SMVG5H strain

\section{LITERATURE CITED}

1. Buzzell, R. I., and Tu, J. C. 1989. Inheritance of a soybean stem-tip necrosis reaction to Soybean mosaic virus. J. Hered. 80:400-401.

2. Cho, E. K. 1995. Identification of Soybean mosaic virus strains and a consideration on genetics of soybean for resistance to SMV strains. Plant Dis. Agric. 1:22-25.

3. Cho, E. K., Choi, S. H., and Cho, W. T. 1983. Newly recognized Soybean mosaic virus mutants and sources of resistance in soybeans. Res. Rep. ORD (S.P.M.U.). 25:18-22.

4. Cho, E. K., Chung, B. J., and Lee, S. H. 1977. Studies on identification and classification of soybean virus disease in Korea. (Etiology of a necrotic disease of Glycine max.) Plant Dis. Rep. 61:313-317.

5. Cho, E. K., and Chung, K. W. 1986. Strains of Soybean mosaic virus causing soybean necrotic disease in Korea. Korean J. Breed. 18:150-153.

6. Cho, E. K., and Goodman, R. M. 1979. Strains of soybean mosaic virus: Classification based on virulence in resistant soybean cultivars. Phytopathology 69:467-470.

7. Edwardson, J. R., Christie, R. G., and Ko, N. J. 1984. Potyvirus cylindrical inclusionsSubdivision IV. Phytopathology 74:11111114.

8. Hammond, J. 1998. Serological relationships between the cylindrical inclusion proteins of potyviruses. Phytopathology 88:965-971.

9. Hayes, A. J., Ma, G., Buss, G. R., and Saghai Maroof, M. A. 2000. Molecular marker mapping of $R s v 4$, a gene conferring resistance to all known strains of Soybean mosaic virus. Crop Sci. 40:1434-1437.

10. Jayaram, C., Hill, J. H., and Miller, W. A. 1992. Complete nucleotide sequences of two Soybean mosaic virus strains differentiated by response of soybean containing the $R s v$ resistance gene. J. Gen. Virol. 73:2067-2077.

11. Kiihl, R. A. S., and Hartwig, E. E. 1979. Inheritance of reaction to Soybean mosaic virus in soybeans. Crop Sci. 19:372-375.

12. Kim, J. S., and Lee, E. J. 1991. A new virulent strain of Soybean mosaic virus infecting SMV resistant soybean cultivar, Deogyou. Korea J. Plant Pathol. 7:37-41.

13. Kim, Y. H., Kim, O. S., Lee, B. C., Im, D. J. and Choi, J. K. 2000. Distribution and diversity of Soybean mosaic virus strains in Korea Korean J. Plant Pathol. 16:179.

14. Kim, Y. H., Kim, O. S., Lee, B. C., Roh, J. H., Kim, M. K., Im, D. J., Hur, I. B., and Lee, S. H. 1999. Detection of Soybean mosaic virus using RT-PCR. Korean J. Crop Sci. 44:253255.

15. Kim, Y. H., Lee, B. C., Kim, O. S., Roh, J. H. Kim, M. K., Im, D. J., and Hur, I. B. 1999. Isolation and comparison of two strains of Soybean mosaic virus, G5H and G7H. Korean J. Plant Pathol. (abstract presentation book). p. 48.

16. Kim, Y. H., Roh, J. H., Kim, M. K., Im, D. J., and Hur, I. B. 1997. Plant growth and seed 
transmission in vegetable soybean "Seokryangputkong" infected with virus disease in field. RDA. J. Crop Prot. 39:19-24.

17. Kim, Y. H., Roh, J. H., Kim, M. K., Im, D. J., Lee, B. H., and Lee, S. C. 1996. Affection of SMV-G5H strain on plant growth and seed chemical composition of soybean variety, Danyeobkong. Korean J. Crop Sci. 41:340347.

18. Lee, S. H. 1981. Studies on virus disease occurring in various crops in Korea. Res. Rep. RDA. 23:62-74.
19. Sano, Y., Tanahashi, M., Kawata, M., and Kojima, M. 1997. Comparative studies on Soybean mosaic virus strain B and C: Nucleotide sequences of the capsid protein genes and virulence in soybean cultivars. Ann. Phytopathol. Soc. Jpn. 63:381-384. 